\title{
Long-term air temperature changes in Ljubljana (Slovenia) in comparison to Trieste (Italy) and Zagreb (Croatia)
}

\author{
Darko OGRIN ${ }^{\text {a* }}$
}

\begin{abstract}
The cities of Ljubljana, Trieste and Zagreb are proximate in terms of distance but differ in terms of geographical and climatic conditions. Continuous meteorological measurements in these cities began in the mid-19 ${ }^{\text {th }}$ century. The 100-year trends of changes in mean annual and seasonal air temperatures for these cities are presented here, evaluating the differences between them which result from their different geographical and climatic positions. Differences in trends between Ljubljana and Zagreb that result from different measurement histories and the impact of urban climate are also presented: the impact of city growth on air temperatures in Ljubljana after 1950 was not completely eliminated in the process of data homogenization. The lowest air warming trends occur in the maritime climate of Trieste (mean annual air temperature: $+0.8^{\circ} \mathrm{C} \times 100 \mathrm{yr} r^{-1}$ ), where measurements were continuously performed in the densely built-up section of the city. The strongest trends occur in Ljubljana, mainly due to city growth (mean annual air temperature: $+1.1^{\circ} \mathrm{C} \times 100 \mathrm{yr}^{-1}$ ). Comparing the linear trends in Zagreb-Grič and in Ljubljana, the impact of Ljubljana`s urban heat island on the 100-year warming trend was assessed at about $0.2^{\circ} \mathrm{C}$, at $0.3-0.4^{\circ} \mathrm{C}$ for the trend after 1950 , and if non-homogenized data are used, at about $0.5^{\circ} \mathrm{C}$.
\end{abstract}

Keywords: climate change in the instrumental period; long-term temperature trends; urban heat island; Ljubljana (Slovenia); Trieste (Italy); Zagreb (Croatia)

\section{Introduction}

During the last 25 years, much attention has been devoted to historical climatology, which investigates climates of the past. One of the main reasons for this increased interest can certainly be sought in contemporary global and regional climate changes and oscillations, manifested in various ways. In Slovenia, for example, such changes began to occur towards the end of the 1980 s, initially as green and mild winters, then followed by a period of very hot and dry summers, and recently, in addition to a general increase in temperatures, an ever greater frequency of exceptional weather events has been observed. In order to properly evaluate these events - to establish whether they already anticipate a changed climate or whether they are just the result of normal weather and climatic variability, and to prepare scenarios of the future climate and its (possible) impacts on natural and social environments - it is necessary to be intimately acquainted with the history of the climates, both in the pre-instrumental period and in the instrumental period, for which measurement and observational data from meteorological stations are available.

To establish the changeability of climate in Slovenia during the instrumental period of over one hundred years, four meteorological stations can primarily be taken into account. Two of them have been operated on Slovenian territory, i.e. Ljubljana and Maribor, and two in the direct vicinity, i.e. Trieste and Zagreb. These stations began with measurements and observations in the mid $-19^{\text {th }}$ or the second half of the $19^{\text {th }}$ century and have collected continuous series of data of sufficient quality. Temperature and precipitation data have been collected in Trieste since 1841, in Ljubljana since 1851, in Zagreb since 1862, and in Maribor since 1876. Trieste exemplifies very well climatic changes in Slovenian areas with moderate Mediterranean climate, while for Ljubljana areas with the sub-Alpine variety of the moderate continental climate of central Slovenia, and Maribor and Zagreb exemplify the moderate continental climate of east Slovenia (sub-Pannonian climate) (Ogrin, 1996; Ogrin and Plut, 2009). Measurements in the mountainous regions began only after World War II, e.g. at Kredarica (2,537 m a.s.l.) in 1954 (Povše, 1984). Data from Villacher Alpe in Austrian Carinthia (2,160 m a.s.l.) are applicable for establishing climatic changes in the Slovenian Alps from the mid-19th century onwards. The series was composed of the data from the two high-elevation stations of Hochobir and Villacher Alpe, and homogenized within the framework of the HISTALP project (www.zamg.ac.at/histalp/). The data were used in several studies dealing with the eastern part of the Alps (e.g. Auer et al., 2007; Brunetti et al., 2009; Colucci and Guglielmin, 2014; Gabrovec et al., 2014).

The main goal of this research was to establish the changes in mean annual air temperatures (MAAT) and mean seasonal air temperatures (MSAT) as the regional response of Ljubljana to global warming, with a comparison to Trieste and Zagreb. The emphasis is on the comparison of 100-year temperature trends. The three cities are located in close vicinity: Ljubljana is located about $100 \mathrm{~km}$ either from Trieste or from Zagreb. These cities are either mediumsized (Ljubljana: 279,000 inhabitants; Trieste: 205,000 inhabitants), or larger (Zagreb: 780,000 inhabitants), and they differ in their geographical and climatic positions (see Fig. 1). Trieste lies on the northernmost rim of the Adriatic, i.e. the Mediterranean Sea, and has a moderate variety of Mediterranean climate. Ljubljana is situated on the continental side of the Alpine-Dinaric barrier, where the features of mountain and continental climates combine. Due

\footnotetext{
${ }^{a}$ Department of Geography, Faculty of Arts, University of Ljubljana, Ljubljana, Slovenia (*corresponding author:
} D.Ogrin, e-mail:darko.ogrin@ff.uni-lj.si) 
to its position on the western rim of the Pannonian Basin, Zagreb has more pronounced continental climate features. Similar climatic conditions to those of Zagreb also occur in Maribor, but preference was given to Zagreb because its data series is longer and of a higher quality. Additionally, data from Maribor were studied recently (Žiberna, 2011). Meteorological measurements in Ljubljana, Trieste and Zagreb began in the mid- $19^{\text {th }}$ century, or in the second half of the $19^{\text {th }}$ century. The history of measurements differs in the three cities; the largest changes in measurement conditions occurred in Ljubljana, and the smallest in Zagreb. Since the impact of city growth in Ljubljana after 1950 was not eliminated in data homogenization, another aim of the research was to assess the impact of the Ljubljana urban heat island on the 100-year temperature trends.

Temperature and precipitation series for Ljubljana, Trieste and Zagreb have been studied individually in the scholarly literature at different times: for Ljubljana Manohin (1952, 1965), Gams and Krevs (1990), KajfežBogataj (1990, 1992), Ogrin (1994, 2003, 2012), Vysoudil and Jurek (2005), Bertalanič et al. (2010), and Dolinar et al. (2010); for Trieste - Polli (1944), Stravisi (1976, 1987), and Brunetti et al. (2006: in the framework of regional data series for the Po plain); and for Zagreb - Goldberg (1953), Šegota (1970, 1981), Juras (1985), Penzar et al. (1992, 1992a), Radič et al. (2004), and Zaninović (2006). Hence, it follows that changes in climate and establishing the trends of these changes have been topical questions not only in recent decades, when opinions have prevailed that humans are the main culprits of current changes, but also that these issues became a subject of research soon after a sufficiently long series of climate data became available. Regardless, a comparison between the hundred-year temperature trends as they occurred in Ljubljana, Trieste and Zagreb has not yet been made.

\section{Data series and methods}

Data series that had been homogenized within the framework of the HISTALP project (www.zamg.ac.at/ histalp) served as the basis for the analysis of air temperature changes in Ljubljana, Zagreb and Trieste. In this work, MAAT and MSAT were employed. Average values, standard deviations, linear trends, and 20-year moving averages and extreme values were calculated or assessed using the Excel package. Statistical significance of the trends was tested by means of the Mann-Kendall test (XLSTAT, Addinsoft 1995-2014). The data series are as follows: the 1851-2010 period for Ljubljana, 1841-2009 for Trieste, and 1862-2010 for Zagreb-Grič.

To establish the impact of the urban climate of Ljubljana on the 100-year trends, non-homogenized data were also used. Their database was composed of published series of data over many years for Ljubljana (Krevs, 1986; Klimatografija Slovenije, 1995), Trieste (Polli, 1944; Stravisi, 1976) and Zagreb (Penzar et al., 1992). The database was completed for Ljubljana over the last 20 years with the data from the archives of the National Meteorological Service at the Slovenian Environment Agency (Agencija RS za okolje/ARSO). The 1986-2009 data for Trieste were obtained from the Institute of Marine Sciences in Trieste (Istituto Talassografico Sperimentale di Trieste/ISMAR),

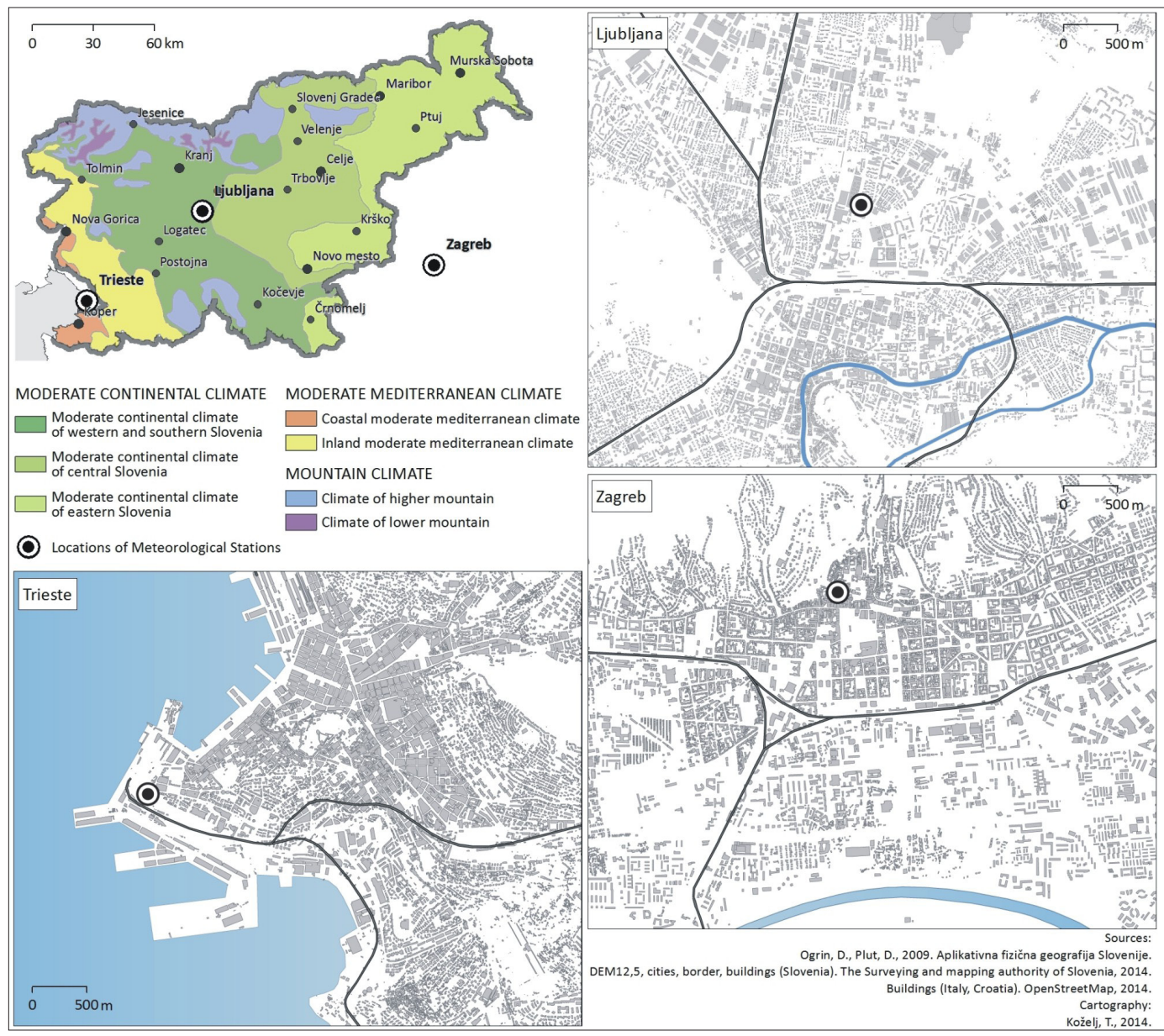

Fig. 1: Climate Types in Slovenia and Locations of Meteorological Stations in Ljubljana, Trieste and Zagreb 
and the 1990-2010 data for Zagreb from the archives of the Hydrometeorological Institute of Croatia (Državni hidrometeorološki zavod Republike Hrvatske).

The basic problem in analysing the series of climate data over many years and in establishing changeability and climatic trends arises from the lack of homogeneity in the data series. In order to obtain reliable results, the meteorological stations should have operated at the same places all of the time, their surroundings should not have significantly changed, nor the technology and methodology of measurements or observations. If this is not the case, it is then essential to have detailed information (i.e. metadata) about the history of observations, the methodologies used for any given weather station, and any time lags.

The stations of Ljubljana and Trieste have changed their locations and instrumentation several times in their history, while the Zagreb station has only changed its micro-location and instrumentation. With respect to the homogeneity of data series, the best station is the one in Zagreb because it has operated at Grič (157 m a.s.l.) throughout the study period. Due to extending the Royal Secondary Modern School there, only in the initial period of measurements was the Stevenson screen moved from the northern to the southern wing of the building; however, it was at all times located on the northern side, on the first-floor window sill. It was mainly due to the world-famous geophysicist Andria Mohorovičić that the station was not moved; on the basis of his own observations he was familiar with the characteristics of the city's climate and was aware of the impact that moving the station could have on the homogeneity of the measured data (Mohorovičić, 1897; Herak et al., 2011). The Zagreb-Grič station has a complete series of temperature (and precipitation) data, since its operation did not stop even during the First and the Second World Wars, despite certain troubles (Katušin, 2011).

The stations of Ljubljana and Trieste were both moved longer distances within the two cities. The Trieste station has an advantage over the one in Ljubljana with respect to data homogeneity, however, because it was moved only within the continuously built-up quarter of the city, and the history of its temperature measurements in individual periods is also better documented. On the grounds of this evidence, the basic series of temperature measurements was rectified and homogenized also in the past, so that it corresponds to measurements such as they would have been if the station had operated all the time in the present location in the centre of the city, not far from the sea (Polli, 1944; Stravisi, 1976).

In spite of the corrections made for Ljubljana, its data are the least homogeneous, due to a more varied history, a somewhat poorer knowledge of measurement circumstances in individual periods, and a greater number of interpolated values. Above all it is due to moving the station after the Second World War to the northern fringe of the city (Bežigrad, 299 m a.s.l.). According to Trontelj (2000), after the station was moved in 1948, measurements were carried out on a "large meadow" which was gradually builtup in the following decades, and thus the measurement circumstances were significantly changed. Therefore, in the temperature series for Ljubljana the impact of urban climate is still present also in the case of homogenized data, with more explicit trends in the latest decades. This was used to advantage in the estimation of the impact of the urban heat island on the air warming trend.

\section{Climate types in Slovenia}

Due to its position in temperate latitudes at the transition of the Alps to the Dinaric range and of the Mediterranean to the Pannonian Basin, Slovenia has an explicit transitional type of climate, which results from the interaction between maritime and continental air masses. As well, local climate conditions are rather strongly influenced by the very strong diversity of landforms and differences in heights. As a result, there are contacts between the mountain (Alpine), Mediterranean and continental (Pannonian) climates, which interact in Slovenia. These three climate types are

\begin{tabular}{|c|c|c|}
\hline Ljubljana* & Trieste $^{* *}$ & Zagreb-Gričc*** \\
\hline $\begin{array}{l}\text { 1850-1852: Telegraph office of the Railway } \\
\text { station, } 1^{\text {st }} \text { floor - east, then at the fringe of } \\
\text { the city, } 298 \mathrm{~m} \text { a.s.l. }\end{array}$ & $\begin{array}{l}\text { 1841-1856: Imperial-Royal Academy of } \\
\text { Commerce and Maritime Studies, 4th floor } \\
\text { - north, } 20 \text { m a.s.l. }\end{array}$ & $\begin{array}{l}\text { 1861-1864: The Great secondary School, } 1^{\text {st }} \\
\text { floor - north wing of the building }\end{array}$ \\
\hline $\begin{array}{l}\text { 1853-1895: Prečna ulica street, } 295 \text { m, } \\
298 \text { m, } 290 \text { m a.s.l.; data for } 1863 \text { and } 1864 \\
\text { are missing, city centre }\end{array}$ & $\begin{array}{l}\text { 1856-1868: Imperial-Royal Academy, } 5^{\text {th }} \\
\text { floor, north, } 24 \mathrm{~m} \text { a.s.l. }\end{array}$ & $\begin{array}{l}\text { 1864: Stevenson screen relocated to the } 1^{\text {st }} \\
\text { floor of the south wing }\end{array}$ \\
\hline $\begin{array}{l}\text { 1895-1919: precipitation measurements, } \\
\text { Levstikova ulica street, } 297 \text { m a.s.l. }\end{array}$ & $\begin{array}{l}\text { 1868-1902: Marine observatory (the roof of } \\
\text { Academy, north, } 27 \mathrm{~m} \text { a.s.l. }\end{array}$ & $\begin{array}{l}\text { 1861-1891: meteorological measurements } \\
\text { and observations managed by I. Stožir }\end{array}$ \\
\hline $\begin{array}{l}\text { 1895-1924: Secondary school in Vegova } \\
\text { ulica street, station relocations within the } \\
\text { building, } 306 \text { m, } 304 \text { m, } 297 \text { m a.s.l.; city } \\
\text { centre } \\
\text { 1921-1922: parallel air temperature } \\
\text { measurements at Šiška and in Šlajmerjeva } \\
\text { ulica street }\end{array}$ & $\begin{array}{l}\text { 1902-1919: Marine observatory (villa } \\
\text { Basevi), Stevenson screen, } 67 \text { m a.s.l. }\end{array}$ & $\begin{array}{l}\text { 1892: observations taken over by A. } \\
\text { Mohorovičić, gradual replacement of } \\
\text { instruments }\end{array}$ \\
\hline $\begin{array}{l}\text { 1921-1948: the University building, } \\
\text { Institute of Geography, station relocations } \\
\text { within the building, } 309 \mathrm{~m}, 305 \mathrm{~m}, 295 \mathrm{~m} \\
\text { a.s.l; town centre }\end{array}$ & $\begin{array}{l}\text { 1919-1938: Royal Oceanographic Institute, } \\
\text { Passeggio S. Andrea, Stevenson screen, } 10 \\
\text { m a.s.l. }\end{array}$ & $\begin{array}{l}\text { 1896: Secondary School moves to a new } \\
\text { location, Meteorological observatory } \\
\text { remains in its original location }\end{array}$ \\
\hline $\begin{array}{l}\text { 1948- : Bežigrad, Celjska (Vojkova) ulica } \\
\text { street, } 299 \text { m a.s.l.; fringe of the city, later } \\
\text { densely built-up }\end{array}$ & $\begin{array}{l}\text { 1938- : Oceanographic Institute, a cluster } \\
\text { of buildings was built on its eastern side, } \\
10 \mathrm{~m} \text { a.s.l. }\end{array}$ & $\begin{array}{l}\text { Uninterrupted daily recording of climate } \\
\text { elements since } 1861,157 \mathrm{~m} \text { a.s.l. }\end{array}$ \\
\hline
\end{tabular}

Tab. 1: Overview of the history of meteorological observations in Ljubljana, Trieste and Zagreb. Note: * Gavazzi, 1925; Trontelj, 2000; ** Polli, 1944; Stravissi, 1976; *** Katušin, 2011; Herak et al., 2011 
characterized by atypical features if compared to 'proper' mountain, Mediterranean and continental climates, whose main characteristics are combined; therefore, the three types often receive the prefix "sub" in Slovenia (sub-Mediterranean, sub-continental, sub-Alpine climates) or they are defined as "moderate" (Mediterranean, continental, mountain) (Ogrin, 1996; Ogrin and Plut, 2009, p. 88). Because of this explicit transition of climate types, climatic division and the determination of borders between climate types and sub-types, as well as their naming, are difficult. In general, with increasing distance from the Alps and the High Dinaric plateaus in the direction towards the east and northeast of Slovenia, continental climate features are intensified; towards the south and southwest the Mediterranean features increase; while with increasing altitude in the Alps and the High Dinaric plateaus, the characteristics of mountain climate begin to prevail.

To the south and southwest of the Alpine-Dinaric barrier, the moderate Mediterranean climate prevails, due to the landforms that open towards the Adriatic and the Mediterranean. This area has the greatest number of days with sunshine in Slovenia $\left(2,100-2,400 \mathrm{~h} \times \mathrm{yr}^{-1}\right)$, thus the greatest number of clear days and the lowest number of cloudy days. The mean air temperature of the coldest month is above $0{ }^{\circ} \mathrm{C}$, and over $20^{\circ} \mathrm{C}$ of the warmest month. Due to the influence of the sea, autumn and winter temperatures are mainly higher if compared to those inland. The precipitation amount ranges from 1,000 $\mathrm{mm}$ along the coast to $1,700 \mathrm{~mm}$ towards the inland. Most of it usually falls in October or November, a secondary maximum occurs at the turn of spring into summer (May, June), while in July and August, drought usually occurs. In the lower-lying areas along the Gulf of Trieste, where the city of Trieste is located, average January temperatures are above $4{ }^{\circ} \mathrm{C}$ and July temperatures above $22^{\circ} \mathrm{C}$ (coastal sub-type of moderate Mediterranean climate). The inland sub-type has slightly lower temperatures and a larger precipitation amount. All the data referred to above relate to the period 1971-2000.

The moderate continental humid climate is typical of the larger part of Slovenia. Because continental characteristics combine with the highland and Mediterranean ones, and because continental features intensify in the direction from the Alps and High Dinaric plateaus towards the east and northeast, three sub-types of moderate continental climate can be discerned. The moderate continental climate of west and south Slovenia, including Ljubljana, is - due to their position in the sub-Alpine mountains and in the area of the Dinaric barrier (therefore also sub-Alpine climate) - characterized by large precipitation amounts (1,300-2,500 mm of annual precipitation, 1971-2000), with the precipitation maximum in autumn. The moderate continental climate of east Slovenia occurs in the hilly and lowland areas in the east and northeast of the country which opens towards the Pannonian Basin, on the margin of which Zagreb is located. The temperature and precipitation regimes are the most continental-like in this part of Slovenia. The lowlands warm up intensely in summer, and cool in winter. Spring temperatures are on the level of autumn temperatures or even slightly higher. If compared to the overall situation in Slovenia, these areas receive little precipitation - from 800 to 1,000 mm annually (19712000) - since the air masses that reach them are rather dry because they are located at the lee of the Alpine-Dinaric barrier. In spite of the summer precipitation maximum, summers in east and northeast Slovenia are at the verge of drought due to the relatively low amounts of precipitation and high temperatures.

The mountain (Alpine) climate that prevails in the Alpine world and the Pohorje range, as well as in the highest areas of the High Dinaric plateaus, is characterized by the average air temperature of the coldest month dropping below $-3{ }^{\circ} \mathrm{C}$, and of the warmest month - up to the timberline - rising to more than $10^{\circ} \mathrm{C}$. The mountain climate in Slovenia could also be defined as sub-Alpine (sub-mountain), since the region is less massive and lower than the Central Alps for example, and it also lacks a real nival zone. Due to lower altitudes and less massive features, and because of the very small central mountain mass, the timberline in Slovenian mountains runs at lower heights than in the Central Alps. It is also greatly influenced by the limestone-dolomite base, which is the cause of great height differences in landforms and steep slopes, as well as by intense windiness, cloudiness and a lot of precipitation on the southernmost and SW rims of the Alps and High Dinaric plateaus. In the most massive central part of the Julian Alps, the timberline runs at about $1,900 \mathrm{~m}$, and in the slightly lower and less massive Kamnik-and-Savinja Alps it runs between 1,700 m and $1,800 \mathrm{~m}$; on the southern and SW rims of the Julian Alps it drops to $1,600-1,700 \mathrm{~m}$ and on the highest ridges of the Dinaric plateaus to 1,450-1,600 m (Lovrenčak, 2007). The timberline is the demarcation between the climates of the higher and the lower mountain types. The climate of the lower mountain world occurs also in some mountain valleys, basins and high-lying karst depressions, where July temperatures equal those in continental Slovenia, whereas January temperatures, mainly because of intense temperature inversions, are lower than $-3{ }^{\circ} \mathrm{C}$. Insolation is poor in summers because of convective cloudiness but, in contrast, winters on the mountain peaks are very sunny. An outstanding feature is the large precipitation amount (from 1,700 to over $3,200 \mathrm{~mm}$ of annual precipitation, 1971-2000) which decreases towards the east.

\section{Results and discussion}

\subsection{The trends of mean annual and seasonal air temperatures in Ljubljana, Zagreb and Trieste}

Mean annual air temperature (MAAT) shows the same variability in Ljubljana and Zagreb but is slightly lower in Trieste. The differences in seasonal variability between these cities are larger. Winter temperatures in Ljubljana and Zagreb typically exhibit greater variability, whereas in Trieste greater variability in temperatures is specific to spring and winter. Generally, the winters (and in Trieste also the springs) manifest the most explicit air warming trends since the mid- $19^{\text {th }}$ century.

Of the three cities, Ljubljana shows the most distinctive air warming trends (see Tab. 2), although it was initially anticipated that such trends would prove to be higher in Zagreb, due to its more explicit continental character of temperature regime.

Trends in the three cities are shown in Figure 2. Without exception, seasonal air temperatures in Ljubljana have been rising since the mid- $19^{\text {th }}$ century. The warming trend is most obvious in winter (by $+1.4^{\circ} \mathrm{C} \times 100 \mathrm{yr}^{-1}$ ), which means that winter temperatures have increased since the mid- $19^{\text {th }}$ century by slightly more than $2{ }^{\circ} \mathrm{C}$. Until the beginning of the $20^{\text {th }}$ century, winters were below the average, but in the 
middle of its first half, a series of warm winters occurred, and in the following decades winter temperatures were on the level of about the 150-year average. From the 1980s onwards an explicit trend of winter temperature increase was observed. Winter is followed by spring $\left(+1.1^{\circ} \mathrm{C} \times 100 \mathrm{yr}^{-1}\right)$, and the same trend is also demonstrated in the increase of MAAT. Summer temperatures have increased more intensely in the last 25 years, when the mean summer temperature has been $1.5^{\circ} \mathrm{C}$ higher than the average over 160 years, and the linear trend for the whole period amounts to $+0.8^{\circ} \mathrm{C} \times 100 \mathrm{yr}^{-1}$. All the trends are statistically significant.
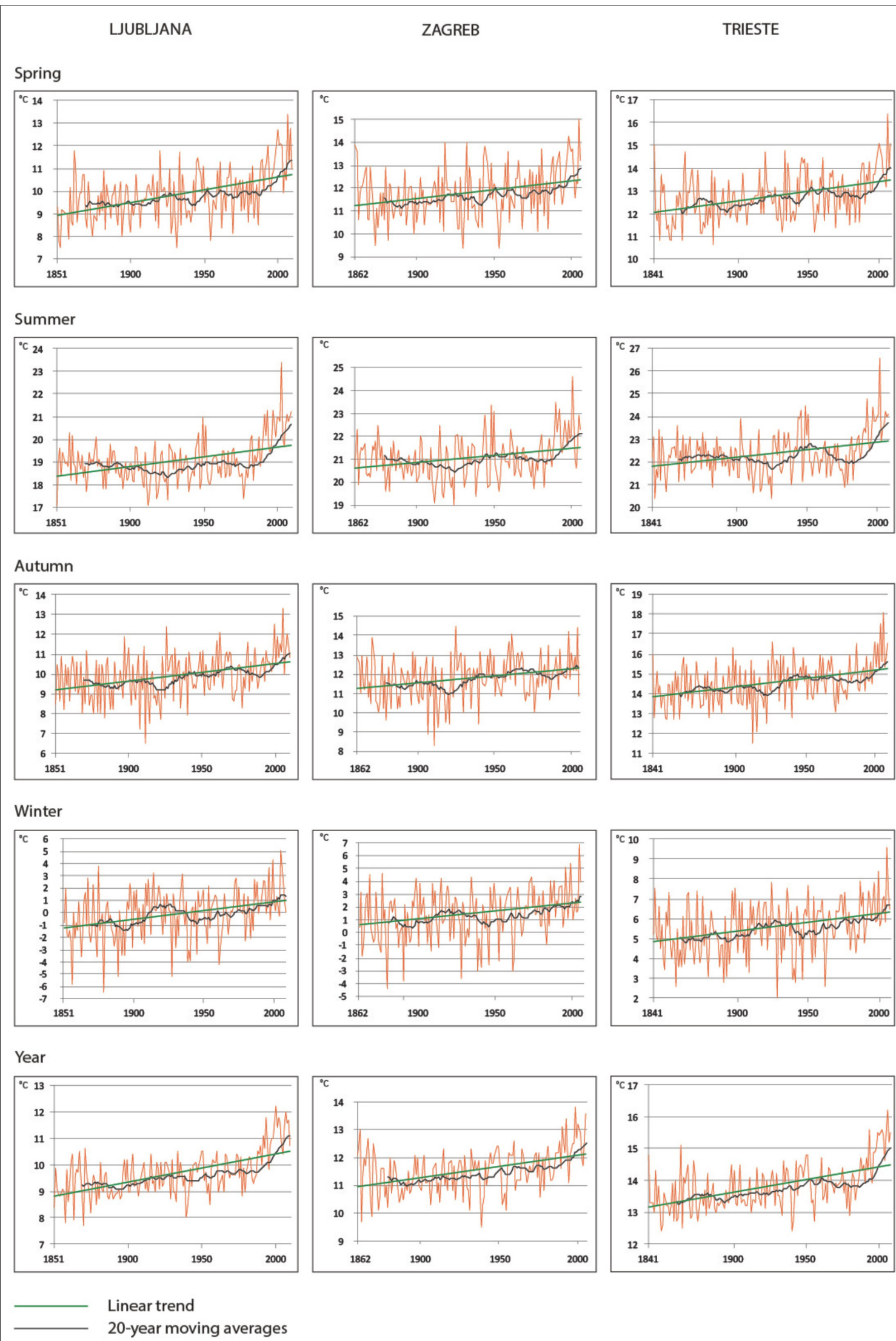

20-year moving averages

Fig. 2: Changes in Mean Air Temperatures in Ljubljana (1851-2010), Zagreb (1862-2010) and Trieste (1851-2009) 


\begin{tabular}{|c|c|c|c|c|c|c|c|}
\hline & Mean & $\begin{array}{l}\text { Standard } \\
\text { deviation }\end{array}$ & $\begin{array}{c}\text { Lowest } \\
\text { temperature }\end{array}$ & $\begin{array}{c}\text { Highest } \\
\text { temperature }\end{array}$ & $\begin{array}{c}\text { Trend*: } \\
{ }^{\circ} \mathrm{C} \times 100 \mathbf{y r}^{-1}\end{array}$ & $\begin{array}{l}\text { Four warmest } \\
\text { seasons/years }\end{array}$ & $\begin{array}{c}\text { Four coolest } \\
\text { seasons/years }\end{array}$ \\
\hline Spring & 9.9 & 1.1 & $\begin{array}{c}7.5 \\
(1932)\end{array}$ & $\begin{array}{c}13.4 \\
(2007)\end{array}$ & +1.1 & $\begin{array}{l}2007,2009,2000, \\
2002,\end{array}$ & $\begin{array}{l}1932,1853,1955, \\
1958,\end{array}$ \\
\hline Summer & 19.0 & 1.0 & $\begin{array}{c}17.1 \\
(1851,1913)\end{array}$ & $\begin{array}{c}23.4 \\
(2003)\end{array}$ & +0.8 & $\begin{array}{l}2003,1994,1998 \\
2010\end{array}$ & $\begin{array}{l}1851,1913, * * \\
1926,1918,1978\end{array}$ \\
\hline Autumn & 9.9 & 1.1 & $\begin{array}{c}6.5 \\
(1912)\end{array}$ & $\begin{array}{c}13.3 \\
(2006)\end{array}$ & +0.9 & $\begin{array}{l}2006,2000,1926, \\
1963,\end{array}$ & $\begin{array}{l}1912,1908,1915, \\
1922,\end{array}$ \\
\hline Winter & -0.1 & 1.8 & $\begin{array}{c}-6.5 \\
(1879 / 80)\end{array}$ & $\begin{array}{c}5.1 \\
(2006)\end{array}$ & +1.4 & $\begin{array}{l}\text { 2006/07, 2000/01, } \\
\text { 1876/77, 1997/98, }\end{array}$ & $\begin{array}{l}\text { 1879/80, 1857/58, } \\
\text { 1890/91, 1928/29, }\end{array}$ \\
\hline Year & 9.7 & 0.8 & $\begin{array}{c}7.7 \\
(1871)\end{array}$ & $\begin{array}{l}12.2 \\
(2000)\end{array}$ & +1.1 & $\begin{array}{l}2000,2007,1994, \\
2002,\end{array}$ & $\begin{array}{l}1871,1858,1864, \\
1940,\end{array}$ \\
\hline
\end{tabular}

Tab. 2: Changes in Air Temperatures in Ljubljana in the period 1851-2010 (in ${ }^{\circ} \mathrm{C}$ ). Note: * All trends are statistically significant according to the Mann-Kendall test ( $\alpha=5 \%$ ); ** Two seasons have the same mean air temperature

The coldest year in the studied period was 1871, and the warmest was 2000 . Very warm years have mainly occurred in a row since 2000 . The coldest winters were in the first 100 years of measurements. Very warm winters are typical above all for the last two decades (the warmest winter 2006/07) and of the early $20^{\text {th }}$ century, when they were followed by a period of fast decrease in winter temperatures. The warmest summer occurred in 2003. In addition to the hot summers of the past two decades, some had already occurred at the beginning of measurements and in the mid $20^{\text {th }}$ century. In contrast, cool summers in Ljubljana occurred at the beginning of measurements and in the first half of the $20^{\text {th }}$ century.

Zagreb shows similar tendencies in air temperature changes to Ljubljana, but the trends are less explicit (see Tab. 3). Even in this case, winters have warmed most in the past 150 years (trend $+1.2^{\circ} \mathrm{C} \times 100 \mathrm{yr}^{-1}$ ) and they have been $1.8^{\circ} \mathrm{C}$ warmer in recent years than in the $1860 \mathrm{~s}$. They are followed by the springs $\left(+0.8^{\circ} \mathrm{C} \times 100 \mathrm{yr}^{-1}\right)$. MAATs in recent years have been one degree higher than those at the beginning of measurements. The warming trend is registered at $+0.9^{\circ} \mathrm{C} \times 100 \mathrm{yr}^{-1}$. All the trends are statistically significant. Most of the warmest years in Zagreb have also occurred in the last 15 years, whereas the coolest years were in the $19^{\text {th }}$ century, and one in the $20^{\text {th }}$ century, i.e. 1940.

Air warming trends in Trieste, where maritime climate features prevail, are slightly weaker than those in Ljubljana and Zagreb (Tab. 4). Both Ljubljana and Zagreb - the latter more markedly - have a continental position; besides, the impact of urban climate on temperature regime is more explicit in Ljubljana. The biggest differences occur in winter temperatures, which show that the winter warming trend in Trieste is $0.3^{\circ} \mathrm{C}$ smaller than that in Zagreb, and $0.5{ }^{\circ} \mathrm{C}$ smaller than that in Ljubljana. These differences are also smaller in the case of the other seasons. The linear trend of MAAT in Trieste is $+0.8^{\circ} \mathrm{C} \times 100 \mathrm{yr}^{-1}$, which equals the level of the 100-year trends in the major part of Europe (Beniston et al., 1998); however, it does not apply to Ljubljana because its warming trend explicitly exceeds these values.

The coldest year in Trieste was 1940, whereas all other very cold years occurred in the second half of the $19^{\text {th }}$ century. As well, the coldest winters occurred during the first 80 years of measurements, with the coldest one in 1928/29 which is well remembered for the great damage done by frost to olive trees. After this frost, the number of olive groves in the littoral part of Slovenia radically declined, and in some regions (Goriška brda) olive growing was dropped until the 1980s (Ogrin, 2007). The severe cold of the winter of 1928/29, particularly in February 1929, also affected the mainland of Slovenia. There are numerous reports on frosts that caused damage to fruit trees and forest trees, many rivers froze, livestock in stables froze as well as wine and field products in cellars, people ran short of fuel, transport was blocked due to the cold, railway transport in particular because steam locomotives froze, schools were closed, etc. (Trontelj, 1997). The hottest summer in the history of measurements in Trieste occurred in 2003. Very hot summers occurred in Trieste in the last decade and in the mid- $20^{\text {th }}$ century. Cool summers, in contrast, occurred at the beginning of the measurements,

\begin{tabular}{|c|c|c|c|c|c|c|c|}
\hline & Mean & $\begin{array}{l}\text { Standard } \\
\text { deviation }\end{array}$ & $\begin{array}{c}\text { Lowest } \\
\text { temperature }\end{array}$ & $\begin{array}{c}\text { Highest } \\
\text { temperature }\end{array}$ & $\begin{array}{c}\text { Trend*: } \\
{ }^{\circ} \mathrm{C} \times 100 \mathbf{y r}^{-1}\end{array}$ & $\begin{array}{l}\text { Four warmest } \\
\text { seasons/years }\end{array}$ & $\begin{array}{c}\text { Four coolest } \\
\text { seasons/years }\end{array}$ \\
\hline Spring & 11.8 & 1.1 & $\begin{array}{c}9.4 \\
(1932,1955)\end{array}$ & $\begin{array}{l}15.0 \\
(2007)\end{array}$ & +0.8 & $\begin{array}{l}2007,2009,2000 \\
1920,1934^{* *}\end{array}$ & $\begin{array}{l}1932,1955,1875, \\
1883,\end{array}$ \\
\hline Summer & 21.1 & 0.9 & $\begin{array}{c}19.0 \\
(1926)\end{array}$ & $\begin{array}{c}24.6 \\
(2003)\end{array}$ & +0.7 & $\begin{array}{l}2003,1992,1950 \\
1994\end{array}$ & $\begin{array}{l}1926,1913,1919, \\
1940^{* *}\end{array}$ \\
\hline Autumn & 11.8 & 1.1 & $\begin{array}{c}8.3 \\
(1912)\end{array}$ & $\begin{array}{c}14.5 \\
(1926)\end{array}$ & +0.7 & $\begin{array}{l}1926,2006,2000, \\
1963,\end{array}$ & $\begin{array}{l}\text { 1912, 1908, 1915, } \\
1921,1941,\end{array}$ \\
\hline Winter & 1.5 & 2.0 & $\begin{array}{c}-4.4 \\
(1879 / 80)\end{array}$ & $\begin{array}{c}6.9 \\
(2006)\end{array}$ & +1.2 & $\begin{array}{l}\text { 2006/07, 2000/01, } \\
\text { 1997/98, 2008/09, }\end{array}$ & $\begin{array}{l}\text { 1879/80, 1890/91, } \\
\text { 1928/29, 1939/40, }\end{array}$ \\
\hline Year & 11.5 & 0.8 & $\begin{array}{c}9.5 \\
(1940)\end{array}$ & $\begin{array}{l}13.8 \\
(2000)\end{array}$ & +0.9 & $\begin{array}{l}2000,2007,1994 \\
2008,2009^{* *}\end{array}$ & $\begin{array}{l}\text { 1940, 1864, 1871, } \\
1933,\end{array}$ \\
\hline
\end{tabular}

Tab. 3: Changes in Air Temperatures in Zagreb in the period 1862-2010 (in ${ }^{\circ} \mathrm{C}$ ). Note: * All trends are statistically significant according to the Mann-Kendall test $(\alpha=5 \%) ; * *$ Two seasons/years have the same mean air temperature 


\begin{tabular}{|l|c|c|c|c|c|l|l|}
\hline & Mean & $\begin{array}{c}\text { Standard } \\
\text { deviation }\end{array}$ & $\begin{array}{c}\text { Lowest } \\
\text { temperature }\end{array}$ & $\begin{array}{c}\text { Highest } \\
\text { temperature }\end{array}$ & $\begin{array}{c}\text { Trend*: } \\
{ }^{\circ} \mathbf{C} \times \mathbf{1 0 0} \mathbf{~ y r}^{-1}\end{array}$ & \multicolumn{1}{|c|}{$\begin{array}{l}\text { Four warmest } \\
\text { seasons/years }\end{array}$} & \multicolumn{1}{|c|}{$\begin{array}{c}\text { Four coolest } \\
\text { seasons/years }\end{array}$} \\
\hline Spring & 12.8 & 1.4 & $\begin{array}{c}10.6 \\
(1883)\end{array}$ & $\begin{array}{c}16.4 \\
(2007)\end{array}$ & +0.9 & $\begin{array}{l}2007,2001,2009, \\
1841,\end{array}$ & $\begin{array}{l}1883,1845,1853, \\
1861,\end{array}$ \\
\hline Summer & 22.4 & 0.9 & $\begin{array}{c}20.4 \\
(1843)\end{array}$ & $\begin{array}{c}26.6 \\
(2003)\end{array}$ & +0.6 & $\begin{array}{l}2003,1994,1950, \\
1998,\end{array}$ & $\begin{array}{l}1843,1926,1851, \\
1913,\end{array}$ \\
\hline Autumn & 14.6 & 1.0 & $\begin{array}{c}11.5 \\
(1912)\end{array}$ & $\begin{array}{c}18.1 \\
(2006)\end{array}$ & +0.8 & $\begin{array}{l}2006,2004,1926, \\
1987,\end{array}$ & $\begin{array}{l}1912,1915,1922, \\
1851,1856^{* *}\end{array}$ \\
\hline Winter & 5.5 & 1.3 & $\begin{array}{c}2.0 \\
(1928 / 29)\end{array}$ & $(2006)$ & +0.9 & $\begin{array}{l}2006 / 07,2000 / 01, \\
1987 / 88,1997 / 89,\end{array}$ & $\begin{array}{l}1928 / 29,1857 / 58, \\
1867 / 68,1890 / 91,\end{array}$ \\
\hline Year & 13.8 & 0.7 & $\begin{array}{c}12.4 \\
(1940)\end{array}$ & $\begin{array}{c}16.2 \\
(2007)\end{array}$ & +0.8 & $\begin{array}{l}2007,2003,1994, \\
2006,2009 * *\end{array}$ & $\begin{array}{l}1940,1850, * * \\
1864,1858,1860,\end{array}$ \\
\hline
\end{tabular}

Tab. 4: Changes in Air Temperatures in Trieste in the period 1841-2009 (in ${ }^{\circ} \mathrm{C}$ ). Note: * All trends are statistically significant according to the Mann-Kendall test $(\alpha=5 \%)$; ** Two seasons/years have the same mean air temperature

in the second decade of the $20^{\text {th }}$ century, and at the end of the 1970s and beginning of the 1980s. The period after the mid-1980s typically has seen a tendency towards a rapid increase in air temperature.

\subsection{Estimation of the urban heat island (UHI) impact on air warming trends in Ljubljana}

The distinctive trend of air warming in Ljubljana particularly in the last 30 years - that greatly exceeds the world average (Dolinar and Vertačnik, 2010) is the result of several factors. Due to the complex history of the meteorological station, it is not possible to exclude completely the influence of the several relocations of the measuring station and the way measurements were taken on the result, in spite of the data homogenization that was carried out. All of the circumstances of measurements in individual periods are not known, especially those in the initial decades when air temperature was measured at non-standard times. The expansion of the city in the second half of the $20^{\text {th }}$ century was certainly the main reason, however, since this factor could not be eliminated in data homogenization (Bertalanic et al., 2010). After the relocation of the meteorological station to the margin of the city in 1948, the surrounding areas became densely built up in the following decades and were thus transformed from a suburban to a completely urban environment, which resulted in the measurements falling under the impact of the UHI. According to the research carried out by Jernej (2000), Ljubljana has a singlecell and stable heat island, where the city centre is warmer than its surroundings by about $1^{\circ} \mathrm{C}$ for the annual average, by 1.2 to $1.5^{\circ} \mathrm{C}$ in the summer months, and by 0.4 to $0.5^{\circ} \mathrm{C}$ in winter. Differences between the highest temperatures in the centre and the lowest ones in the southern marshy outskirts of Ljubljana are from 5 to $7{ }^{\circ} \mathrm{C}$, and on clear winter nights and the subsequent emergence of fog, when snow cover still lies outside the city, they can even reach $10^{\circ} \mathrm{C}$.

The impact of the UHI in Ljubljana on temperature trends can be estimated by means of a comparison of trends in Ljubljana and Zagreb before and after 1950, when intense urbanization of the surroundings of the Ljubljana meteorological station began (Tab. 5). Between 1862 and 1950, both in Zagreb and Ljubljana, a gradual rise of air temperatures occurred, whether of MAAT or winter, autumn and spring temperatures. Only summer temperatures showed no trend. The warming was somewhat more intensely expressed in Ljubljana, but the differences in trends, with the exception of winter, were not bigger than $0.2{ }^{\circ} \mathrm{C}$. Besides, no trend is statistically significant in Zagreb, while trends in winter and MAAT are statistically significant in Ljubljana. After 1950, the increase in air temperatures soared, in Ljubljana in particular. Its linear trends range between $+1{ }^{\circ} \mathrm{C} \times 50 \mathrm{yr}^{-1}$ (autumn) and $+2.1^{\circ} \mathrm{C} \times 50 \mathrm{yr}^{-1}$ (summer). Except in winter, the Zagreb trends are markedly weaker, and the autumn months do not show a statistically significant trend.

If winters, which warmed slightly more in Zagreb than in Ljubljana, are ignored, the differences between Ljubljana and Zagreb in the warming trends after 1950 range between 0.4 and $0.7{ }^{\circ} \mathrm{C}$ in the seasons, and $0.4{ }^{\circ} \mathrm{C}$ in MAAT - to the 'benefit' of Ljubljana. If non-homogenized data are used, the difference in MAAT is higher by another tenth of one degree $\mathrm{C}$ (Tab. 5). It is not surprising that the difference between the two cities is greater in the summer, since according to the findings of Jernej (2000) the intensity

\begin{tabular}{|c|c|c|c|c|c|c|c|c|}
\hline & \multicolumn{2}{|c|}{$\begin{array}{c}1862-1950 \\
\left({ }^{\circ} \mathrm{C} \times 100 \mathrm{yr}^{-1}\right) \\
\text { Homogenized data }\end{array}$} & \multicolumn{2}{|c|}{$\begin{array}{c}1862-1950 \\
\left({ }^{\circ} \mathrm{C} \times 100 \mathrm{yr}^{-1}\right) \\
\text { Non-homogenized data }\end{array}$} & \multicolumn{2}{|c|}{$\begin{array}{c}1951-2010 \\
\left({ }^{\circ} \mathbf{C} \times 50 \mathrm{yr}^{-1}\right) \\
\text { Homogenized data }\end{array}$} & \multicolumn{2}{|c|}{$\begin{array}{c}1951-2010 \\
\left({ }^{\circ} \mathrm{C} \times 50 \mathrm{yr}^{-1}\right) \\
\text { Non-homogenized data }\end{array}$} \\
\hline & Ljubljana & Zagreb & Ljubljana & Zagreb & Ljubljana & Zagreb & Ljubljana & Zagreb \\
\hline Spring & $+0.4^{*}$ & +0.3 & $+1.1^{*}$ & +0.7 & $+2.0^{*}$ & $+1.6^{*}$ & $+2.1^{*}$ & $+1.7^{*}$ \\
\hline Summer & +0.05 & +0.05 & +0.2 & +0.3 & $+2.1^{*}$ & $+1.4^{*}$ & $+2.2^{*}$ & $+1.5^{*}$ \\
\hline Autumn & +0.6 & +0.4 & +0.4 & +0.8 & $+1.0^{*}$ & +0.4 & $+1.2^{*}$ & +0.5 \\
\hline Winter & +0.9 & +0.4 & +1.5 & +1.3 & $+1.9 *$ & $+2.0^{*}$ & $+1.7^{*}$ & $+1.6^{*}$ \\
\hline Year & $+0.4^{*}$ & +0.2 & $+0.8^{*}$ & $+0.8^{*}$ & $+1.7^{*}$ & $+1.3^{*}$ & $+1.8^{*}$ & $+1.3^{*}$ \\
\hline
\end{tabular}

Tab. 5: Comparison of linear trends of air temperatures in Ljubljana and Zagreb in the periods 18621950 and 1951-2010. Note: * Statistically significant trends according to the Mann-Kendall test $(\alpha=5 \%)$ 


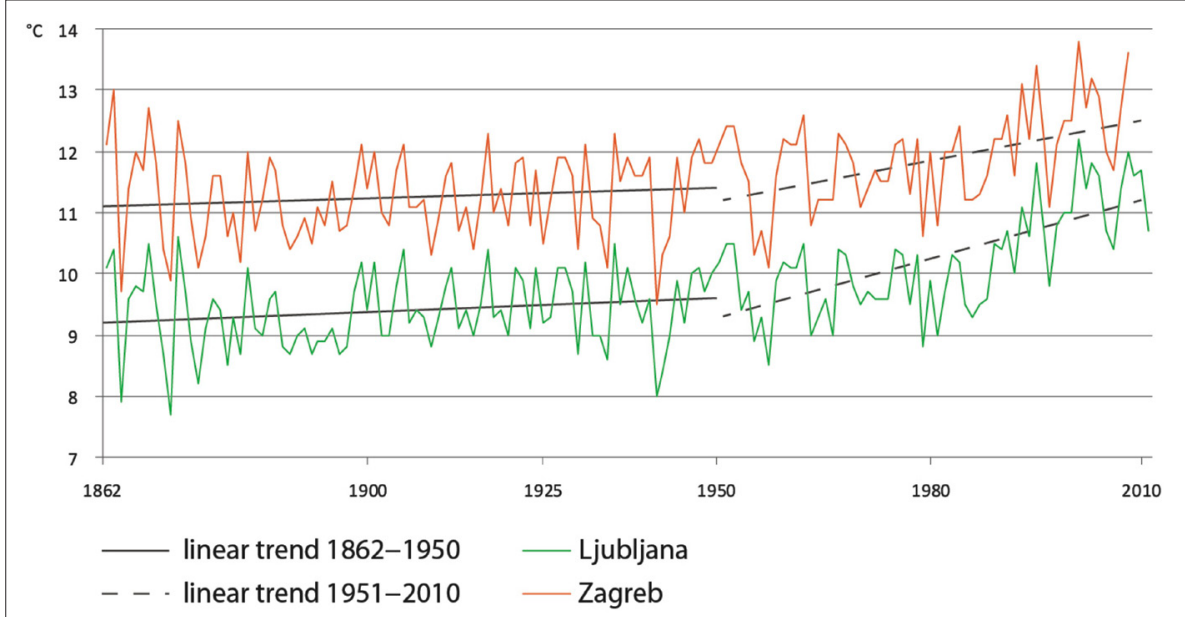

Fig. 3: Linear trends of MAAT in Ljubljana and Zagreb in the periods 1862-1950 and 1951-2010

of the Ljubljana UHI is highest during this season. Also in other cities of a similar size and structure as Ljubljana, the UHI is most intense in summer, e.g. in Brno in the Czech Republic (Dobrovolný et al., 2012). In our opinion, most of the differences between the warming trends of Ljubljana and Zagreb after 1950 can be ascribed to the impact of the UHI or the expansion of Ljubljana and the increased building densities in the surroundings of the meteorological station (see Fig. 3). If these factors are taken into account, the values of the 100-year trends in Ljubljana are slightly higher than the warming trends in most of Europe, but they are more comparable to them.

\section{Conclusions}

The comparison between the 100-year temperature trends in Ljubljana, Zagreb and Trieste has shown that air warming trends are the least explicit in Trieste and the most explicit in Ljubljana. The increasing trend in MAAT was $+1.1^{\circ} \mathrm{C} \times 100 \mathrm{yr}^{-1}$ in Ljubljana, $+0.9^{\circ} \mathrm{C} \times 100 \mathrm{yr}^{-1}$ in Zagreb, and $+0.8^{\circ} \mathrm{C} \times 100 \mathrm{yr}^{-1}$ in Trieste. In all three cities it was the winters that warmed the most, but it should be noted that the warming trend of winters in Trieste equals the warming trend of spring temperatures. The lowest warming trends occur in summer and autumn air temperatures.

The results for Trieste had been anticipated, since warming trends in maritime climate areas are generally less explicit than those in continental climate areas, even though the maritime character of Trieste climate is less explicit. The city is located at the northernmost rim of the Adriatic, which cuts deep into the European continent, but the Northern Adriatic is a shallow sea and has poor water exchange with the South Adriatic or the Mediterranean. Consequently, the water temperature regime in the Gulf of Trieste is to a certain degree closer to a larger lake than a sea. The weaker maritime character of the Trieste climate is also evident from the comparison of trends in Trieste with those in Padua, where the warming trend of MAAT at the end of the $19^{\text {th }}$ century and in the $20^{\text {th }}$ century is $0.5^{\circ} \mathrm{C}$ lower than that in Trieste $\left(+0.34^{\circ} \mathrm{C} \times 100 \mathrm{yr}^{-1}\right.$ : see Cocheo and Camuffo, 2000).

The warming trend in Ljubljana, after 1950 in particular, is more explicit than the warming trend in Zagreb, although the latter city's climatic features are more continental than those in Ljubljana. The Ljubljana trend of the last 30 years also greatly exceeds the world average (Dolinar and Vertačnik, 2010). The main reason can be seen in the lateral expansion of the city in the second half of the $20^{\text {th }}$ century, and the urbanization of the surroundings of the meteorological station. Its original suburban position was transformed into an urban one and the station fell intensely under the impact of the UHI. However, it was not possible to take account of this impact in data homogenization (Bertalanič et al., 2010). Through comparison of the trends in Zagreb before the year 1950 with those after that year, the impact of the UHI on the warming trend in Ljubljana after 1950 was assessed at $0.3-0.4{ }^{\circ} \mathrm{C}$ (with nonhomogenized data, at $0.5^{\circ} \mathrm{C}$ ), and on the 100 -year trend at about $0.2{ }^{\circ} \mathrm{C}$.

\section{Acknowledgements}

This study was carried out within the scope of the project: "The adaptation patterns of human activities to the environmental changes after Last Glacial Maximum in Slovenia", J6-4016, funded by the Slovenian Research Agency. My thanks also go to Dr. F. Crisciani, Dr. S. Ferraro, Dr. R. R. Colucci and D. Mlinek for their valuable help in collecting meteorological data, and to Dr. A. Filipčić for providing references on the climate of Zagreb, as well as to the reviewers for their helpful instructions which contributed to a higher quality for this paper.

\section{References:}

Arhiv Urada za meteorologijo ARSO (Archives of Slovenian Hydrometeorological Institute, Slovenian Environmental Agency, Ministry of Agriculture and Environmental). Mean monthly and annual temperatures for the period 1991-2011 [online] [Cit. 15.06.2013]. Available at: http:// meteo.arso.gov.si/met/sl/app/webmet/\#webmetf

AUER, E., BÖHM, R., JURKOVIC, A., LIPA, W., ORLIK, A., POTZMANN, R., SCHÖNER, W., UNGERSBÖCK, M., MATULLA, C., BRIFFA, K., JONES, P., EFTHYMIADIS, D., BRUNETTI, M., NANNI, T., MAUGERI, M., MERCALL, L., MESTRE, O., MOISSELIN, J. M., BEGERT, M., MÜLLER-WESTMEIER, G., KVETON, V., BOCHNICEK, O., STASTNY, P., LAPIN, M., SZALAI, S., SZENTIMREY, T., CEGNAR, T., DOLINAR, M., GAJIČČAPKA, M., ZANINOVIĆ, K., MAJSTOROVIĆ, Z., NIEPLOVA, E. (2007): HISTALP-historical instrumental climatological surface time series of the Greater Alpine Region. International Journal of Climatology, 27: 17-46. 
BENISTON, M., TOL, R. S. J., DELÉCOLLE, R. HOERMAN, G., IGLESIAS, A., INNES, J., McICHAEL, A. J., MARTENS, W. J. M., NEMESOVA, I., NICHOLLS, R., TOTH, F. L., KOVATS, S., LEEMANS, R., STOJIC, Z. (1998): Regional impacts of climatic change on Europe. Special Report of the Intergovernmental Panel on Climate Change (IPCC), Chapter 5 (pp. 149-185). Cambridge University Press.

BERTALANIČ, R., DEMŠAR, M., DOLINAR, M., DVORŠEK, D., NADBATH, M., PAVČIČ, B., ROETHEL-KOVAČ, M., VERTAČNIK, G., VIČAR Z. (2010): Spremenljivost podnebja v Sloveniji. MOP ARSO, Ljubljana.

BRUNETTI, M., LENTINI, G., MAUGERI, N., NANNI, T., AUER, I., BÖHM, R., SCHÖNER, W. (2009): Climate variability and change in the Greater Alpine Region over the last two centuries based on multi-variable analysis. International Journal of Climatology, 29: 2197-2225.

BRUNETTI, M., MAUGERI, M., MONTI, F., NANNI, T. (2006): Temperature and precipitation variability in Italy in the last two centuries from homogenised instrumental time series. International Journal of Climatology, 26: $345-381$.

COCHEO, C., CAMUFFO, D. (2000): Corrections of systematic errors and data homogenisation in the daily temperature Padova series (1725-1998). Climate Change, 53, (pp. 77-100). Kluwer academic publishers.

COLUCCI, R. R., GUGLIELMIN, M. (2014): Precipitationtemperature changes and evolution of a small glacier in the souteastern European Alps during the last 90 years. International Journal of Climatology, DOI: 10.1002/ joc.4172.

DOBROVOLNÝ, P. et al. (2012): Klima Brna, Víceúrovňová analýza městského klimatu. Masarykova univerzita, Brno.

DOLINAR, M., NADBATH, M., VIČAR, Z., VERTAČNIK, G., PAVČIČ, B. (2010): Spreminjanje podnebja v Sloveniji. In: Cegnar, T. [ed.]: Okolje se spreminja - Podnebna spremenljivost Slovenije in njen vpliv na vodno okolje (pp. 17-35). Ljubljana, MOP ARSO.

DOLINAR, M., VERTAČNIK, G. (2010): Spremenljivost temperaturnih in padavinskih razmer $\mathrm{v}$ Sloveniji. In: Cegnar, T. [ed.]: Okolje se spreminja - Podnebna spremenljivost Slovenije in njen vpliv na vodno okolje (pp. 37-40). Ljubljana, MOP ARSO.

Državni hidrometeorološki zavod Republike Hrvatske/ Meteorological Service of Croatia. Data on mean monthly and annual air temperatures and precipitation heights at meteorological station Zagreb-Grič in the period 1990-2010 (Personal communication 01.10.2012).

GABROVEC, M., HRVATIN, M., KOMAC, B., ORTAR, J., PAVŠEK, M., TOPOLE, M., TRIGLAV ČEKADA, M., ZORN, M. (2014): Vremenske razmere na Triglavskem ledeniku.. In: Kladnik, D., Perko, D. [eds.]: Triglavski ledenik (pp. 75-90).

GAMS, I., KREVS, M. (1990): Ali nam grozi poslabšanje vremena? Ujma, 4: 147-154.

GAVAZZI, A. (1925): O meteoroloških postajah v Sloveniji. Geografski vestnik, 1: 55-64.

GOLDBERG, J. (1953): Prilozi istraživanju klimatskih fluktuacija u Jugoslaviji. Radovi Geofizičkog instituta u Zagrebu, 3(2): 1-27.
HERAK, D., PENZAR, B., HERAK, M. (2011): Ljetopis Geofizičkog zavoda. In: Orlić, M. [ed.]: Nulla dies sine observatione, 150 godina Geofizičkog zavoda u Zagrebu (pp. 9-32). Zagreb, Sveučilište u Zagrebu, Prirodoslovnomatematički fakultet, Geofizički odsjek.

HISTALP, historical instrumental climatological surface time series of the greater alpine region [online]. [Cit. 03.02. 2015]. Available at: http://www.zamg.ac.at/histalp/ dataset/station/cvs.php

CNR-ISMAR Institute of Marine Sciences in Trieste. Mean monthly air temperatures and precipitation heights in the period 1986-2010. Trieste [online]. [Personal communication 03.05.2005 and 11.11.2011].

JERNEJ, S. (2000): Mestna klima. In: Gabrovec, M.; Orožen Adamič, M. [eds.]: Ljubljana, geografija mesta (pp. 117-130). Ljubljana.

JURAS, J. (1985): Neke karakteristike promjene klime Zagreba u poslednjem tridesetlječu. Geofizika, 2: 93-102.

KAJFEŽ -BOGATAJ, L. (1990): Analiza zimskih temperatur zraka v Ljubljani. Zbornik Biotehniške fakultete UL, 55: 7-14.

KAJFEŽ-BOGATAJ, L. (1992): Vpliv pričakovanih klimatskih sprememb na živi svet. Geografija v šoli, 2: 47-55.

KATUŠIN, Z. (2011): Sustavna mreža meteoroloških postaja na području Hrvatske od prvih početaka 1851 do 2011 (Kretanje broja meteoroloških postaja u odnosu na povjesne i organizacione promjene). Prikazi br. 22. Zagreb, Državni hidrometeorološki zavod R Hrvatske pp.

Klimatografija Slovenije (1995). Temperatura zraka 1961-1990. Ljubljana, HMZ R Slovenije.

KREVS, M. (1986): Spremenljivost klime v Ljubljani in Trstu v obdobju 1851-1985. Ljuibljana, Univerza v Ljubljani, Filozofska fakulteta, Oddelek za geografijo.

LOVRENČAK, F. (2007): Zgornja gozdna meja slovenskih Alp, visokih kraških planot in Prokletij. Razprave Filozofske fakultete, $217 \mathrm{pp}$.

MANOHIN, V. (1952): Kratek pregled temperatur in padavin v Ljubljani v stoletni opazovalni dobi 1851-1950. Geografski vestnik, 17: 135-144.

MANOHIN, V. (1965): Nekatere značilnosti zimskih temperatur v Ljubljani v zadnjih 115 letih. RazpravePapers, Društvo meteorologov Slovenije, 6: 5-18.

MOHOROVIČIĆ, A. (1897): Klima grada Zagreba. Rad JAZU, Vol. 131: 72-111.

OGRIN, D. (1994): Modern age climatic fluctuation in the area of the Gulf of Trieste. Geografski zbornik, 34: 5-80.

OGRIN, D. (1996): Podnebni tipi v Sloveniji. Geografski vestnik, 68: 39-56.

OGRIN, D. (2003): Spreminjanje temperature zraka in padavin po letnih časih $\mathrm{v}$ Ljubljani in Trstu $\mathrm{v}$ obdobju 1851-2002. Dela, 20: 115-131.

OGRIN, D. (2007): Olive growing in Slovenian Istria and climatic limitations to its development. Moravian Geographical report, 15(3): 34-40.

OGRIN, D. (2012): Spreminjanje podnebja ob Tržaškem zalivu in projekcije za 21. stoletje. In: Ogrin, D. [ed.]: Geografija stika Slovenske Istre in Tržaškega zaliva, GeograFF 12 (pp. 87-105). Ljubljana 
OGRIN, D., PLUT, D. (2009): Aplikativna fizična geografija Slovenije. Znanstvena založba filozofske fakultete Univerze v Ljubljani.

PENZAR, I., JURAS, J., MARKI, A. (1992): Long-term meteorological measurment at Zagreb: 1862-1990. Geofizika, 9, suppl.

PENZAR, I., JURAS, J., MARKI, A. (1992a): Brief review of climatic fluctuations recorded in Zagreb between 1862 and 1990. Geofizika, 9: 57-67.

POLLI, S. (1944): 100 anni di osservazioni meteorologiche eseguite a Trieste (1841-1940). Parte I: Generalita e serie termometriche, Bol. Soc. Adriatica di scienze Naturali, 40: 5-28.

POVŠE, M. (1984): Imenik ali seznam krajev z vremenskimi postajami v SR Sloveniji in kronološkim pregledom dosedanjih meteoroloških opazovanj. Ljubljana, Elaborat, HMZ Slovenije.

RADIĆ, V., PASARIĆ, N., ŠINIK, N. (2004): Analiza zagrebačkih klimatoloških nizova pomoću empirijski odredjenih prirodnih sastavnih funkcija. Geofizika, 21(1): 15-36.

STRAVISI, F. (1976): Considerazioni statistiche sui valori medi mensili di cinque elementi meteorologici, Trieste 1841-1975. Istituto Sperimentale Talassografico »F. Vercelli«, Publicazione No. 529, Trieste. 53 pp.
STRAVISI, F. (1987): Climatic variations at Trieste during last century. Geofizika, 4: 61-76.

ŠEGOTA, T. (1970): Sekularne fluktuacije temperature u Zagrebu. Geografski glasnik, 32: 39-60.

ŠEGOTA, T. (1981): More About the Secular Fluctuations of Air Temperature in Zagreb, Croatia. Quaestiones Geographicae, 7: 147-154.

TRONTELJ, M. (1997): Kronika izrednih vremenskih dogodkov v 20. stoletju. Ljubljana, HMZ RS.

TRONTELJ, M. (2000): 150 let meteorologije na Slovenskem. Ljubljana, HMZ RS.

VYSOUDIL, M., JUREK, M. (2005): Summer air temperatures in Ljubljana (Slovenia) and Olomouc (Czech Republic) in the period 1961-2000. Dela, 23: 245-257.

ZANINOVIĆ, K. (2006): Trends in indices of temperature extremes in Croatia, 1901-2004. Sixth European Conference on Applied Climatology (ECAC) 4-8 September 2006, Ljubljana, Slovenia, CD Abstracts, A-00470.

ŽIBERNA, I. (2011): Trendi temperatur, višine padavin in vodne bilance v Mariboru v obdobju 1876-2010. Revija za geografijo, 6(1): 23-31.

Initial submission 28 November 2014, final acceptance 17 July 2015

Please cite this article as:

OGRIN, D. (2015): Long-term air temperature changes in Ljubljana (Slovenia) in comparison to Trieste (Italy) and Zagreb (Croatia). Moravian Geographical Reports, 23(3): 17-26. DOI: 10.1515/mgr-2015-0014. 